\title{
LOGISTICS MANAGEMENT OF THE RAIL CONNECTIONS USING GRAPH THEORY: THE CASE OF A PUBLIC TRANSPORTATION COMPANY ON THE EXAMPLE OF KOLEJE DOLNOŚLĄSKIE S.A.
}

\author{
PAWEŁ SOBCZAK, EWA STAWIARSKA, JUDIT OLÁH, \\ JÓZSEF POPP, TOMAS KLIESTIK
}

Corresponding author:

Paweł Sobczak

WSB University, Faculty of Applied Sciences, Department of Engineering Management and Logistics Processes, Poland e-mail: psobczak@wsb.edu.pl

Ewa Stawiarska

Silesian University of Technology, Faculty of Organisation and

Management, Institute of Management, Administration and Logistics, Poland e-mail: ewa.stawiarska@polsl.pl

Judit Oláh

University of Debrecen, Faculty of Economics and Business, Hungary e-mail: olah.judit@econ.unieb.hu

József Popp

University of Debrecen, Faculty of Economics and Business, Hungary e-mail: popp.jozsef@econ.unideb.hu

Tomas Kliestik

School of Expertness and Valuation Institute of Technology and Business in Ceske Budejovice, Czechia e-mail: tomas.kliestik@fpedas.uniza.sk

\section{INTRODUCTION}

According to the information provided in the literature (Sołtysik, 2000), logistics management is a sequence of activities constituting a component within the process for the creation of a company's logistics concept and the implementation of logistics activities using appropriate control and control systems. Logistics management should use a number of tools (Bukowski, 2014) to ensure the effectiveness of actions taken in the supply chain (including the provision of transport services), considering both efficiency and resilience to possible threats. Among other things, logistics management consists of appropriate transport or, specifically, transport services implemented following the principles of logistics (Kerap et al., 2017). 
Transport is an important branch of the economy that affects urban and rural residents and businesses (Mesjasz-Lech, 2014). Consequently, it is important to create efficient and effective transport systems in cities and regions. Such systems should enable the acquisition and maintenance of their users (customers).

Customer acquisition and service require an appropriate level of performance (transport services included) to ensure customer maintenance, which is one of the main tasks in the management of a company for the managerial staff and employees (Witkowski, 1995). Transport companies must meet several requirements to acquire and retain customers. These requirements are mainly related to the level of services, which mainly concerns the quality encompassing:

- travel comfort,

- operating frequency,

- number of connections,

- travel time,

- the cost of travel,

- intermodality.

It is important to note that nowadays, transport companies operate according to free-market principles. Consequently, on the one hand, they have to compete in the services market and, on the other hand, they must cooperate with other service providers operating at the same scope (including the same branch and substitute branches in the industry of the company's operation). The above conditions and difficulties apply to the area of transport services in general and the area of public transport in particular.

As an element of the modern economy, public transport has commercial and social importance. Congestion is a major challenge for urban and metropolitan areas (Badura, 2017). Not only does congestion raise air pollution concerns but also gives rise to social pressure to improve the quality of life. Consequently, efficient transport systems currently play an even more significant role than in previous decades. Also, congestion generates enormous costs and wastes travel time as well as fuel. The United States, for instance, lose 11 billion hours and incur the increase of 11 billion litres in fuel consumption (Szołtysek, 2014).

Since the beginning of the 1990s, private transport has played an increasingly important role in Poland. However, pursuant to some studies of and situations in Western European cities, such as London or Kraków and Katowice in Poland, this type of transport will no longer guarantee efficiency and, most importantly, will not be considered environmentally friendly. The aggravating factor is an especially unfavourable vehicle occupancy rate of a passenger car, averaging at 1.3 people per vehicle. The solution has been proposed in the EU's sustainable transport policy: to improve transport in urban and agglomeration areas by means of efficient and effective public transport.

Poland as well as Europe, take measures to increase the share of public transport at the expense of private transport. These measures include legislative and organisational solutions as well as social actions.

Attractiveness to passengers is a crucial factor in increasing the share of public transport. In this respect, several factors are important, including travel comfort, availability, travel time, and cost. The total effort related to these factors must result in the attractiveness of the public transport superseding the appeal of personal cars. It must be underlined that changing habits is not an easy task to achieve. Thus, public transport services should ensure maximum benefits with minimum costs and time losses (Krykawskyy et al., 2015).

The above problem is not only particular to cities but also agglomerations, such as Wrocław, and some regions, such as the province of Lower Silesia. Additionally, the movement of people from urban to suburban or rural areas has become a growing phenomenon. More and more people choose life or leisure outside cities, especially city centres. However, greater occupational or educational opportunities make the people take trips to large urban centres.

This situation requires an efficient and effective transport system to and from the city as well as inside it. Also, an efficient transport system has a significant impact on the development of a region in economic terms. If a transport system encourages residents to live in a certain area, including a suburb, by facilitating efficient and quick access to the workplace, the attractiveness of such an area significantly increases and brings investments.

Currently, a bus is the most popular mode of public transport in Poland. It has several advantages, including high flexibility and availability, but also many disadvantages, such as the environmental unfriendliness and operating on the same roads as cars. These issues are mitigated using appropriate legislative measures, e.g. the prohibition for personal cars to enter a city, and organisational solutions, such as purchasing buses powered by hydrogen or electricity and introducing bus lanes. However, these actions 
are inadequate to ensure efficient traffic management, especially in city centres and suburban and rural areas.

Rail transport is considered an effective and frequent solution used for linking a city with suburban/ rural areas. Some of the advantages of this mode of transport are high transport capacity, punctuality and safety. Nowadays, regional rail carriers offer high travel comfort using modern rolling stock, which, as mentioned before, is also very important. Besides, it is an important element of the logistics strategy as part of business management.

Several decades after the collapse, the rail system of Poland, including agglomeration and urban areas, is undergoing a revival. Agglomeration or urban networks are being built or rebuilt in every major Polish agglomeration or metropolis.

One network is available in Lower Silesian Voivodeship. One of its main goals is to ensure efficient transport between cities and suburban or rural areas. This network is operated by the railway carrier Koleje Dolnośląskie S.A. Appropriate modelling, optimisation and assessment of connections in the carrier network have a significant impact on ensuring the required level and quality of transport services. Consequently, it is an important element of business management. Furthermore, it is significant in terms of ensuring an adequate level of security and responsiveness to disturbances and risks, many of which are currently very difficult to detect, such as black swan events (Bukowski, 2015). Graph theory, among other things, can be used to evaluate the connection network.

\section{CHARACTERISTICS OF THE CARRIER KOLEJE DOLNOŚLĄSKIE}

According to available information (Koleje Dolnośląskie, 2016), Koleje Dolnośląskie was established by the Authorities of Lower Silesian Voivodeship on 28 December 2007. The company is owned by
Tab. 1. List of railway vehicles owned by Koleje Dolnośląskie

\begin{tabular}{|l|r|}
\hline \multicolumn{2}{|c|}{ Diesel traction UNITS } \\
\hline \multicolumn{1}{|c|}{ VeHICLE TYPE } & \multicolumn{1}{|c|}{ No. OF ITEMS } \\
\hline SA106 & 1 \\
\hline SA109 & 2 \\
\hline SA132 & 1 \\
\hline SA134 & 8 \\
\hline SA135 & 9 \\
\hline SA139 & 4 \\
\hline Sum: & 25 \\
\hline \multicolumn{2}{|c|}{ ELECTRIC MULTIPLE UNITS } \\
\hline \multicolumn{1}{|c|}{ VeHICLE TYPE } & No. OF ITEMS \\
\hline 31WE & 10 \\
\hline 36WEa & 6 \\
\hline EN57 & 4 \\
\hline Sum: \\
Source: (Koleje Dolnośląskie, 2016). \\
\hline
\end{tabular}

the Regional Government of Lower Silesian Voivodeship. The company is tasked to provide passenger rail services with the objective to ensure an efficient regional rail system. The current carrier's rolling stock consists of two groups of vehicles, namely, diesel traction units and electric multiple units. Detailed information is presented in Tab. 1.

In addition to information about the current state of the rolling stock, the dynamics of the carrier's development is also very important. Tab. 2 presents the number of passengers transported by the carrier and transport work performed in 2011-2017. The data presented in Tab. 2 is shown graphically in Fig. 1 and 2.

As shown in Fig. 1, the number of passengers in the period from 2011 grew almost exponentially, while transport performance increased linearly. This indicates an intensive development of the carrier and high popularity of transport services. Significantly, according to the data of the Central Statistical Office, the population of Dolnośląskie Voivodeship was 2903710 , which ranks it 5th in Poland in terms of the population and 3 th in terms of population density.

In addition to modern rolling stock, an adequate level of service requires a well-organised structure of services provided, with the network of connections as one of its main elements. The structure of connections

Tab. 2. Number of transported passengers and transport work performed by the Koleje Dolnosląskie in 2011-2017

\begin{tabular}{|l|c|c|c|c|c|c|c|}
\hline & \multicolumn{9}{|c|}{ YEAR } & \multicolumn{1}{|c|}{} \\
\cline { 2 - 8 } & $\mathbf{2 0 1 1}$ & $\mathbf{2 0 1 2}$ & $\mathbf{2 0 1 3}$ & $\mathbf{2 0 1 4}$ & $\mathbf{2 0 1 5}$ & $\mathbf{2 0 1 6}$ & $\mathbf{2 0 1 7}$ \\
\hline $\begin{array}{l}\text { The number of transported } \\
\text { passengers [mln] }\end{array}$ & 0.900559 & 1.840128 & 2.421163 & 3.603254 & 5.222432 & 7.312884 & 9.380451 \\
\hline Transport work [mln paskm] & 30.128947 & 87.057838 & 115.158880 & 204.665963 & 316.994350 & 391.213509 & 508.047568 \\
\hline
\end{tabular}

Source: (UTK statistical data). 


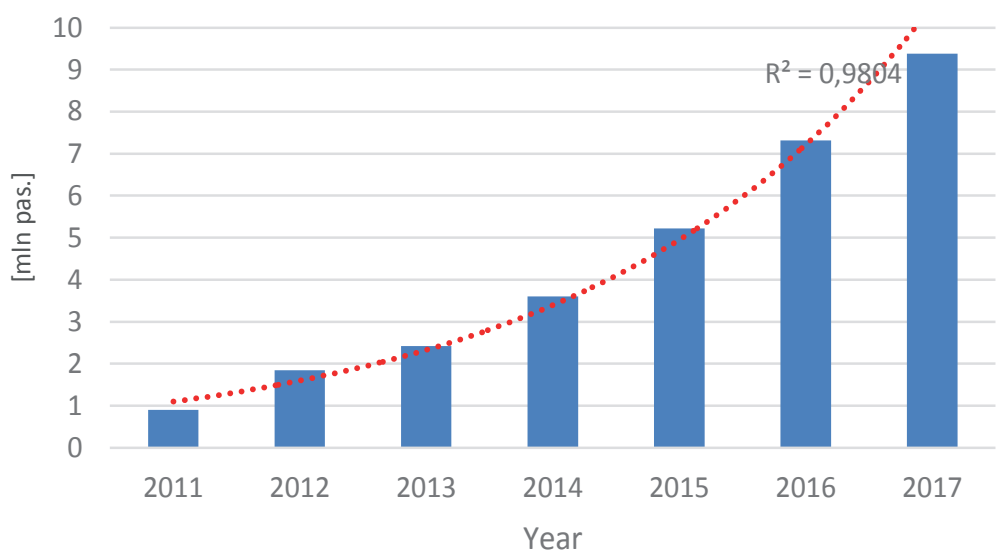

Fig. 1. Number of transported passengers in 2011-2017

Source: own study based on (UTK statistical data).

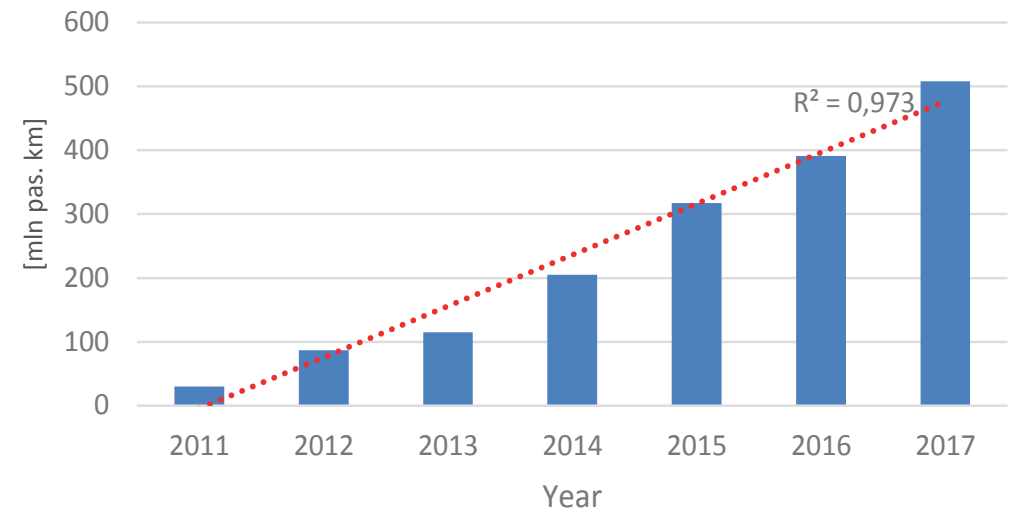

Fig. 2. Transport work in 2011-2017

Source: own study based on (UTK statistical data).

(communication network) of the Koleje Dolnosląskie is shown in Fig. 3.

According to the information provided in Fig. 3, the connections network of Koleje Dolnośląskie is divided into 17 lines that allow connections between the capital of the voivodeship and virtually all larger towns located in the Lower Silesia. Naturally, the service is also available in many smaller towns. It should be stressed that the carrier also offers connections to neighbouring countries (Germany and the Czech Republic) sharing a border with the voivodeship.

In contrast, Fig. 4 shows the existing railway network in the Lower Silesian Voivodeship. Comparison of Fig. 3 and 4 reveals that the carrier's connections network does not utilise all possible existing railway connections in the analysed area. The existing railway network allows making some changes and modifications to the currently used connections network, which may contribute to the further development of the company through increased accessibility of the carrier services. Thanks to the existing network, this availability can be increased without costly infrastructure investments. Certainly, the choice of new connections or the modification of the connections network is not an easy task. Decision taking can be made easier by using graph theory.

\section{GRAPH THEORY IN NETWORK ANALYSIS INCLUDING TRANSPORT NETWORKS}

Transport networks are one of the most important elements of the national and regional economy. Their main task is to ensure a smooth movement from point $\mathrm{A}$ to point $\mathrm{B}$. Therefore, they must be resistant to any interference and ensure an adequate level of security (Dunn \& Wilkinson, 2017).

Current transport systems (just as electric, telecommunications or IT systems) constitute a network of complex connections and links (Eusgeld et al., 


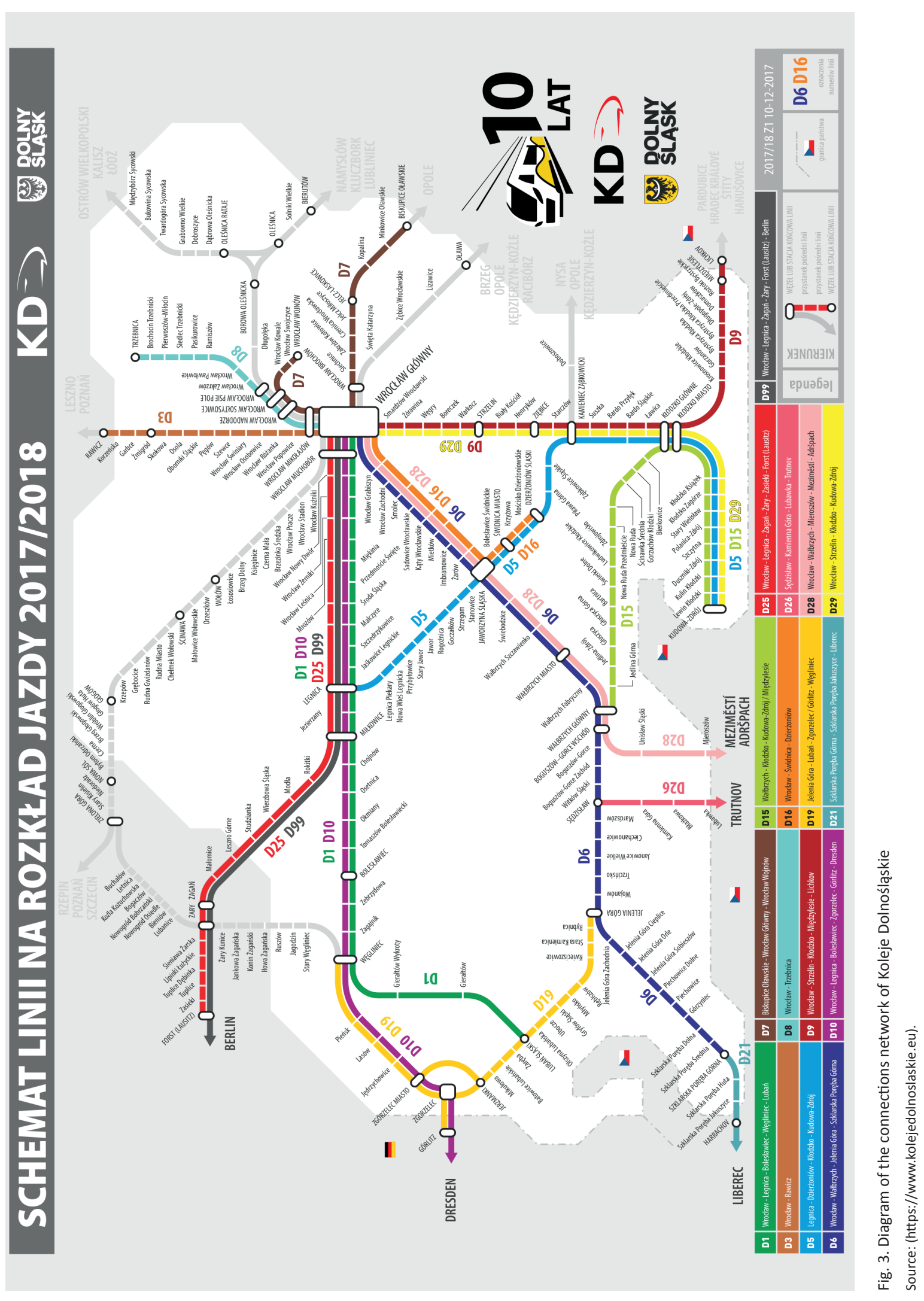




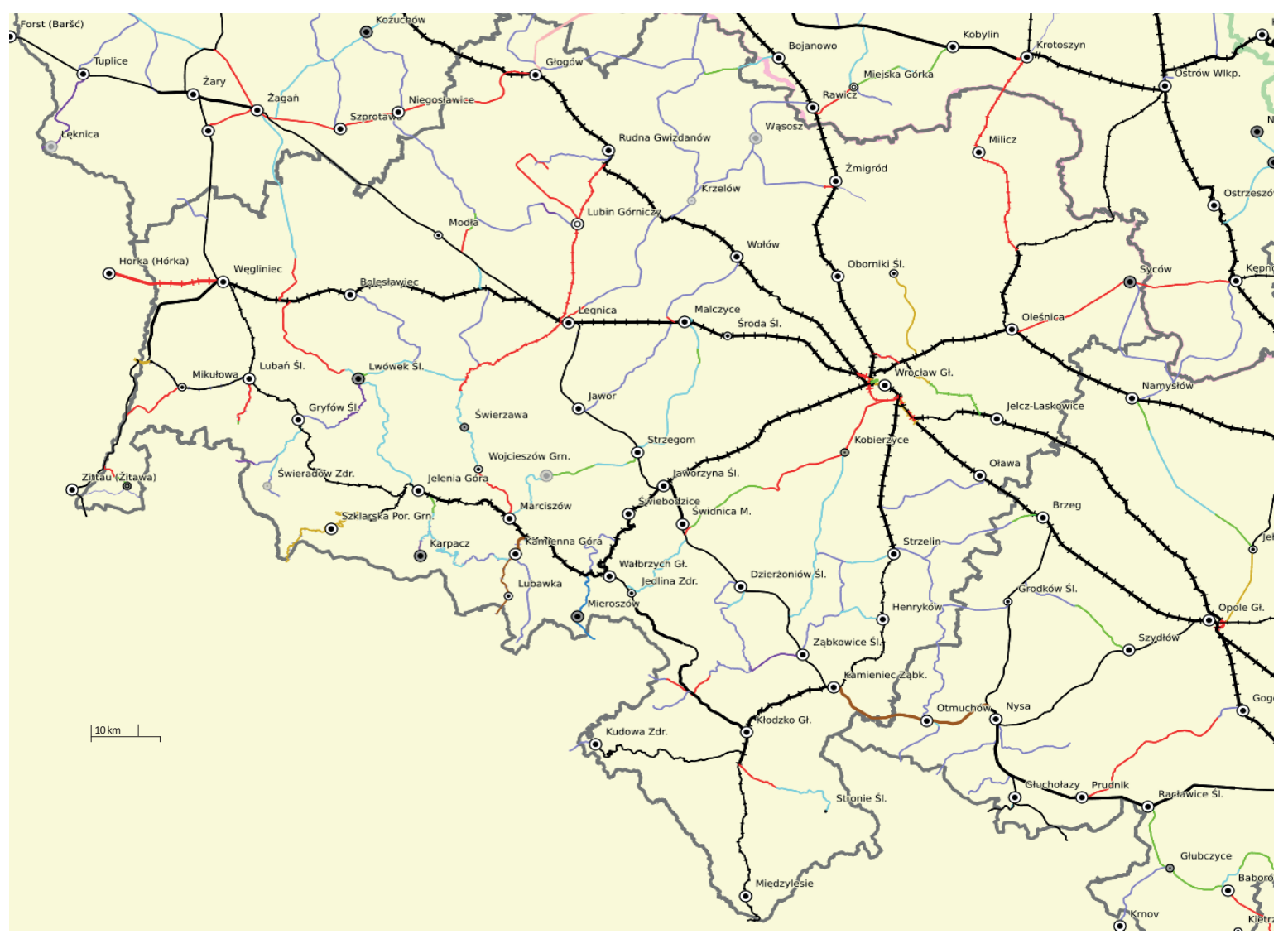

Fig. 4. Railway network in the Lower Silesia Voivodeship

Source: (http://www.bazakolejowa.pl).

2009; La Rovere \& Vestrucci, 2012). This important feature hinders the analysis both from the organisational viewpoint as well as in terms of the resistance to possible disruptions (Infrastructure engineering..., 2011).

Network analysis methods are widely used for the analysis of social networks (Amaral et al., 2000; Arenas et al., 2003; Butts, 2008; Newman et al., 2002; Otte \& Rousseau, 2002; Popp et al., 2018), but also biological networks (Rual et al., 2005), neural networks (Bullmore \& Sporns, 2009; Sporns, 2002; Stam \& Reijneveld, 2007) and computer networks (Valverde \& Solé, 2003).

According to some authors (Dunn \& Wilkinson, 2017; Li et al., 2014; Newman, 2002; Ouyang et al., 2015; Tarapata, 2015; Wilkinso et al., 2012), the methods and coefficients used to analyse social networks can also be effectively applied in the analysis of transport networks.

With the help of graph theory, the article analyses the structural transport network of connections used by the regional rail carrier Koleje Dolnośląskie. According to the information provided in the literature (Amara et al., 2000; Bullmore \& Sporns, 2009; Dunn
\& Wilkinson, 2017; Li et al., 2014; Newman, 2010; Ouyang et al., 2015; Rual et al., 2005; Sporns, 2002; Stam \& Reijneveld, 2007; Tarapata, 2015; Valverde \& Solé, 2003; Wilkinson et al., 2012) transport networks can be analysed using a group of meters that allow obtaining information regarding the characteristics of the analysed network. The meters used to calculate the parameters of individual network nodes and the entire network are also described in publications by other authors (Stawiarska \& Sobczak, 2018; Newman, 2010; Sobczak, 2017; Tarapata, 2015).

The factor allows obtaining information about the role of individual nodes in the network and determining its parameters.

Each network can be described as a collection of nodes and their links:

$$
G=\langle V, E\rangle
$$

where:

$V$ - collection of nodes,

$E$ - collection of their interrelations.

Of course, the following relationship applies to every analysed network:

$$
|V|=N,|E|=M
$$


The most popular measures are described below. Normalised degree $\left(d c_{i}\right)$ for an $i$-th node:

$$
d c_{i}=\frac{k_{i}}{N-1}
$$

where:

$k_{i}-$ degree of this $i$-th node in the network (the number of node connections with other nodes),

$N$ - number of nodes in the network.

The higher is the $d c_{i}$ coefficient value for this $i$-th node, the more important role this node has in the network, or the closer the node is situated to the centre.

Eccentricity $\left(e c_{i}\right)$ of an $i$-th node in the network:

$$
e c_{i}=\max _{j \in V} d_{i j}
$$

where:

$d_{i j}$ - number of links among the nodes, wherein a link is understood as the shortest distance between node $i$ and node $j$.

Eccentricity is defined as a maximum distance between two nodes (http://www.geeksforgeeks.org). The lower is the $e c_{i}$ coefficient value for this $i$-th node, the more important role this node has in the network, or the closer the node is situated to the centre.

Radius $\left(r c_{i}\right)$ of this $i$-th node in the network:

$$
r c_{i}=\frac{1}{\max _{j \in V} d_{i j}}=\frac{1}{e c_{i}}
$$

where:

$d_{i j}$ - number of links among the nodes, where a link is understood as the shortest distance between node $i$ and node $j$,

$e c_{i}-$ eccentricity of this $i$-th node in the network.

The higher is the $r c_{i}$ coefficient value for this $i$-th node, the more important role this node has in the network, or the closer the node is situated to the centre.

Closeness $\left(c c_{i}\right)$ for an $i$-th node in the network:

$$
c c_{i}=\frac{N-1}{\sum_{j \in V} d_{i j}}
$$

where:

$N$ - number of nodes in the network,

$d_{i j}$ - number of links among the nodes, wherein a link is understood as the shortest distance between node $i$ and node $j$.

Closeness measures the average distance from a given node to all other nodes in the network (https:// github.com).

Betweenness $\left(b c_{i}\right)$ for an $i$-th node in the network:

$$
b c_{i}=\sum_{l \in V} \sum_{k \neq l \in V} \frac{p_{l, i, k}}{p_{l, k}}
$$

where:

$p_{l, i, k}$ - number of connections with the lowest number of nodes between nodes $l$ and $k$ (containing node $i$ ), $p_{l, k}$ - number of connections with the lowest number of nodes between nodes $l$ and $\mathrm{k}$ (which do not contain node $i$ ).

Betweenness measures how often a node appears on shortest paths between nodes in the network (https://github.com). The higher is the $b c_{i}$ coefficient value for this $i$-th node, the more important role this node has in the network, or the closer the node is situated to the centre.

Clusterisation $\left(g c_{i}\right)$ of this $i$-th node in the network:

$$
g c_{i}=\frac{2 E_{i}}{k_{i}\left(k_{i}-1\right)}, k_{i}>1
$$

where:

$E_{i}$ - number of links among nodes which are situated closest (neighbours) to the i-th node,

$k_{i}$ - degree of this i-th node in the network (number of node connections to other nodes).

The higher is the gci coefficient value for this $i$-th node, the more important role this node has in the network, or the closer the node is situated to the centre.

Formulas (2)-(8) describe the parameters of particular nodes in a network. However, coefficients used to determine the parameters of an entire network are also applied. These are (Newman, 2010; Tarapata, 2015).

Average shortest paths length $(L)$ :

where:

$$
L=\frac{1}{N(N-1)} \sum_{i \neq j \in V} d_{i j}
$$

$N$ - number of nodes in the network,

$d_{i j}$ - number of links among the nodes, where a link is understood as the shortest distance between node $i$ and node $j$.

The lower is the value of the average shortest path length, the better is the analysed network.

Clusterisation coefficient $(C)$ :

$$
C=\frac{1}{N} \sum_{i \in V} g c_{i}
$$

where:

$N$ - number of nodes in the network,

$g c_{i}-$ clusterisation coefficient.

The higher is the value of the clusterisation coefficient, the better is the analysed network. 
Diameter (D):

$$
D=\max _{i \in V} e c_{i}
$$

where:

$e c_{i}$ - eccentricity of the $i$-th node in the network.

The smaller is the diameter, the better is the network.

Radius of a network $(R)$ :

$$
R=\min _{i \in V} e c_{i}
$$

where:

$e c_{i}$ - eccentricity of the i-th node in the network.

The smaller is the radius of the network, the better is the network.

Average nodes degree $(\bar{k})$ :

$$
\bar{k}=\frac{1}{N} \sum_{i \in V} k_{i}
$$

where:

$\mathrm{N}$ - number of nodes in the network,

$k_{i}$ - degree of this $i$-th node in the network (number of node connections to other nodes).

The higher is the average node degree in the network, the better is the network.

The analysis of coefficients relating to individual network nodes as well as to the network as a whole allows assessing its current status, optimising, and proposing changes and modifications that may contribute to the improvement of network parameters.

The analyses presented below were made using freeware Gephi, which allows analysing the network and its parameters. Gephi is used by researchers for analyses related to networks (Popp et al., 2018;
Zirkelbach et al., 2015), which confirms the effectiveness and, most importantly, the reliability of analysis results obtained with the use of the software (parameters of nodes and networks). The advantage of using the software, in addition to its availability, is also the opportunity to learn about the algorithms used and suggestions for their improvement on websites and the software forum (https://github.com; forumgephi.org).

\section{RESEARCH RESULTS}

As part of the research, the connections network used by Koleje Dolnośląskie was simulated using Gephi. The simulated network is shown in Fig. 5. It presents the analysed network considering the network node degree (a train stop).

Fig. 5 shows the current connections network of the carrier between particular nodes (train stations) that are operated by the carrier. However, the lines between nodes mean the existing connection between the given stations. The size of individual nodes means the size of a given parameter (in Fig. 5, it is the degree of nodes) calculated for each node (train station), i.e. the larger is the size of a given parameter, the greater is the value.

Next, basic network parameters were calculated using Gephi in accordance with formulas described by other authors (Newman, 2010; Sobczak, 2017;

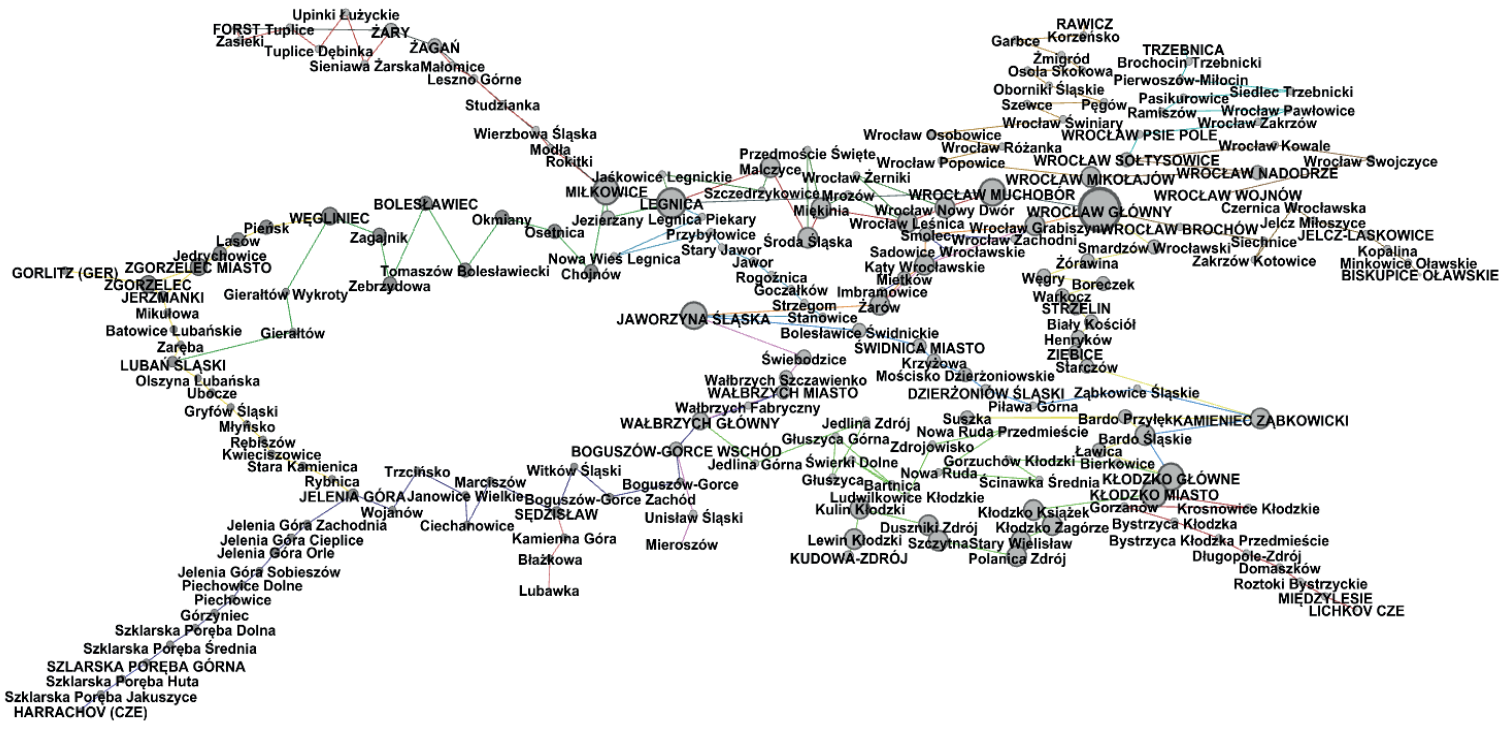

Fig. 5. Connections network used by Koleje Dolnośląskie on the degree of nodes

Source: own elaboration based on (https://www.kolejedolnoslaskie.eu) made using Gephi software. 
Stawiarska \& Sobczak, 2018; Tarapata, 2015). Due to a large volume of calculated data (202 nodes/stops) in Tab. 3, indicators are presented only for selected stops, regarded as main by the carrier (these are mainly node and terminal stations).

The calculated ratios are presented in Tab. 3. For illustrative indicators, their values are presented in a graphical form in Figures 6-8.

As shown in Table 3 and Figures 6-8, the key nodes of the analysed network are the main stops (stations) located in the main cities of the voivodeship. The stations Wrocław, Wrocław Muchobór,
Miłkowice, Legnica, Wałbrzych, Kłodzko (Main and the City) and Jaworzyna Śląska deserve particular attention. It is clearly visible that the centre of the network is concentrated around the main city of the province - Wrocław.

Then, the coefficients determining the state of the network as a whole were calculated. The obtained values of coefficients are presented in Tab. 4 .

The resulting network indicators show that it has a rather good performance, but that can be improved by making some modifications to the connections network.

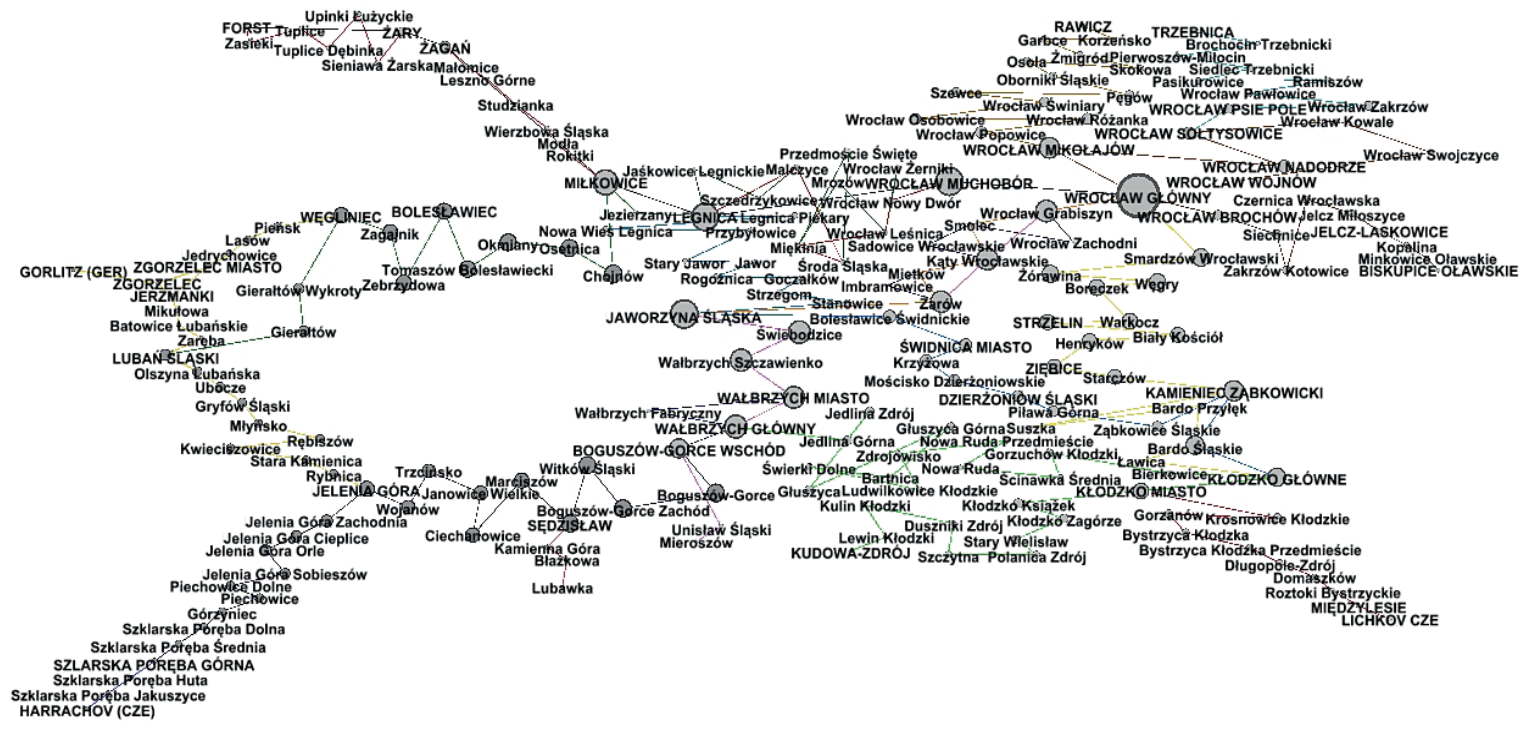

Fig. 6. Betweenness coefficient for the analysed network

Source: own study using Gephi software.

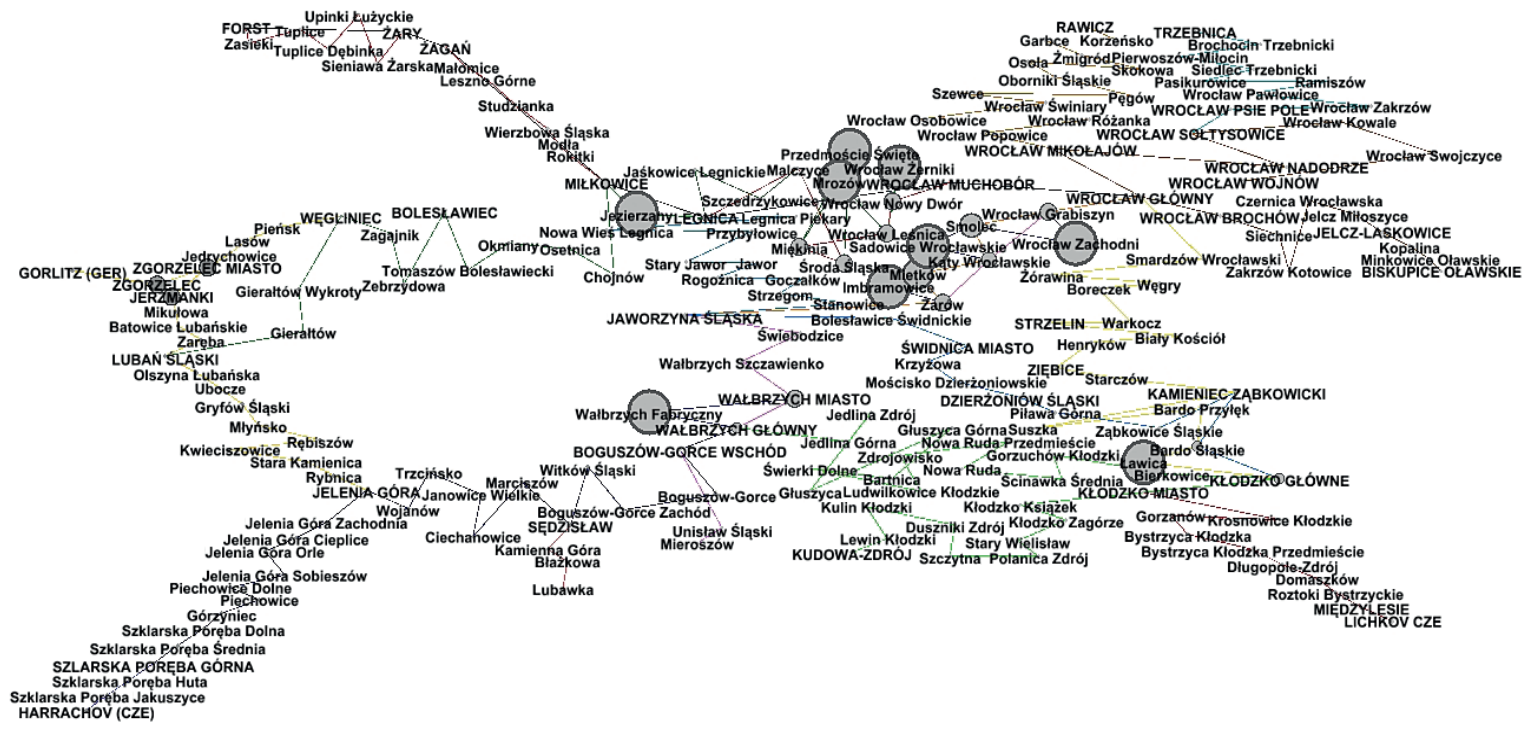

Fig. 7. Clusterisation coefficient for the analysed network

Source: own study using Gephi software. 
Tab. 3. Indicators calculated for selected stops (nodes) of the Koleje Dolnośląskie network

\begin{tabular}{|c|c|c|c|c|c|c|c|}
\hline CITY (NODE) & $\begin{array}{c}\text { NORMALISED } \\
\text { DEGREE }\end{array}$ & $\begin{array}{l}\text { ECCEN- } \\
\text { TRICITY }\end{array}$ & RADIUS & $\begin{array}{l}\text { CLOSENESS } \\
\text { CENTRALITY }\end{array}$ & $\begin{array}{c}\text { BETWEENNESS } \\
\text { CENTRALITY }\end{array}$ & Clustering & $\begin{array}{l}\text { EIGENCENT- } \\
\text { RALITY }\end{array}$ \\
\hline Wrocław Główny & 0.064676617 & 32 & 0.03125 & 0.093358105 & 0.559471814 & 0 & 1 \\
\hline Wrocław Brochów & 0.009950249 & 33 & 0.03030303 & 0.086007702 & 0.07681592 & 0 & 0.147281398 \\
\hline Jelcz-Laskowice & 0.009950249 & 38 & 0.02631579 & 0.061149985 & 0.029552239 & 0 & 0.009281612 \\
\hline Biskupice Oławskie & 0.004975124 & 41 & 0.02439024 & 0.051790776 & 0 & 0 & 0.004272244 \\
\hline Wrocław Mikołajów & 0.029850746 & 33 & 0.03030303 & 0.087429317 & 0.24278607 & 0 & 0.490023117 \\
\hline Rawicz & 0.004975124 & 46 & 0.02173913 & 0.042378242 & 0 & 0 & 0.004272244 \\
\hline Wrocław Nadodrze & 0.019900498 & 34 & 0.02941176 & 0.0812778 & 0.12159204 & 0 & 0.16955391 \\
\hline Wrocław Sołtysowice & 0.019900498 & 35 & 0.02857143 & 0.07587769 & 0.114179104 & 0 & 0.067583692 \\
\hline Wrocław Psie Pole & 0.009950249 & 36 & 0.02777778 & 0.070949523 & 0.07681592 & 0 & 0.019328113 \\
\hline Trzebnica & 0.004975124 & 44 & 0.02272727 & 0.045921864 & 0 & 0 & 0.004272244 \\
\hline Wrocław Wojnów & 0.004975124 & 38 & 0.02631579 & 0.061979648 & 0 & 0 & 0.004483397 \\
\hline Smardzów Wrocławski & 0.019900498 & 33 & 0.03030303 & 0.088351648 & 0.193225376 & 0 & 0.325712893 \\
\hline Strzelin & 0.019900498 & 38 & 0.02631579 & 0.070402802 & 0.164369655 & 0 & 0.059340589 \\
\hline Kamieniec Ząbkowicki & 0.029850746 & 36 & 0.02777778 & 0.065387118 & 0.233827914 & 0 & 0.11909069 \\
\hline Kłodzko Główne & 0.039800995 & 38 & 0.02631579 & 0.060161628 & 0.202862693 & 0.166666667 & 0.386658822 \\
\hline Kłodzko Miasto & 0.039800995 & 39 & 0.02564103 & 0.057346648 & 0.167910448 & 0 & 0.429333981 \\
\hline Międzylesie & 0.009950249 & 47 & 0.0212766 & 0.03993642 & 0.009950249 & 0 & 0.007580234 \\
\hline Lichkov (CZE) & 0.004975124 & 48 & 0.02083333 & 0.03841009 & 0 & 0 & 0.004272244 \\
\hline Kudowa-Zdrój & 0.014925373 & 48 & 0.02083333 & 0.03841009 & 0 & 0 & 0.097813175 \\
\hline Jaworzyna Śląska & 0.039800995 & 28 & 0.03571429 & 0.089852481 & 0.346612407 & 0 & 0.208516098 \\
\hline Świdnica Miasto & 0.019900498 & 30 & 0.03333333 & 0.081015719 & 0.119181586 & 0 & 0.075408434 \\
\hline Dzierżoniów Śląski & 0.014925373 & 33 & 0.03030303 & 0.070974576 & 0.101587174 & 0 & 0.031920644 \\
\hline Wałbrzych Główny & 0.024875622 & 25 & 0.04 & 0.076484018 & 0.271342836 & 0.166666667 & 0.052877195 \\
\hline Wałbrzych Miasto & 0.019900498 & 25 & 0.04 & 0.079227434 & 0.254739462 & 0.333333333 & 0.0561526 \\
\hline Boguszów-Gorce Wschód & 0.019900498 & 25 & 0.04 & 0.073304158 & 0.217688124 & 0 & 0.041094005 \\
\hline Legnica & 0.044776119 & 34 & 0.02941176 & 0.086787565 & 0.334128359 & 0.066666667 & 0.402312847 \\
\hline Wrocław Muchobór & 0.039800995 & 33 & 0.03030303 & 0.090094128 & 0.342473322 & 0 & 0.816298021 \\
\hline Miłkowice & 0.039800995 & 33 & 0.03030303 & 0.083715119 & 0.302567076 & 0.1 & 0.284505544 \\
\hline Żagań & 0.019900498 & 34 & 0.02941176 & 0.077876792 & 0.091044776 & 0 & 0.080547097 \\
\hline Żary & 0.019900498 & 35 & 0.02857143 & 0.072589382 & 0.058358209 & 0 & 0.046911533 \\
\hline Bolesławiec & 0.019900498 & 31 & 0.03225806 & 0.067653989 & 0.172709835 & 0 & 0.060080128 \\
\hline Lubań Śląski & 0.014925373 & 37 & 0.02702703 & 0.055509528 & 0.09962796 & 0 & 0.015623384 \\
\hline Zgorzelec Miasto & 0.024875622 & 38 & 0.02631579 & 0.050616973 & 0.030537606 & 0.333333333 & 0.077011692 \\
\hline Zgorzelec & 0.024875622 & 39 & 0.02564103 & 0.048715463 & 0.009950249 & 0.333333333 & 0.066127548 \\
\hline Jerzmanki & 0.014925373 & 39 & 0.02564103 & 0.049204406 & 0.013329529 & 0.333333333 & 0.041069654 \\
\hline Gorlitz (GER) & 0.009950249 & 40 & 0.025 & 0.046463245 & 0 & 0 & 0.033285248 \\
\hline Sędzisław & 0.014925373 & 29 & 0.03448276 & 0.063207547 & 0.186295141 & 0 & 0.015236981 \\
\hline Jelenia Góra & 0.014925373 & 35 & 0.02857143 & 0.052411995 & 0.161410508 & 0 & 0.015282294 \\
\hline Szlarska Poręba Górna & 0.009950249 & 45 & 0.02222222 & 0.035356201 & 0.029552239 & 0 & 0.009280346 \\
\hline Szklarska Poręba Huta & 0.009950249 & 46 & 0.02173913 & 0.034177861 & 0.019800995 & 0 & 0.008938041 \\
\hline Szklarska Poręba Jakuszyce & 0.009950249 & 47 & 0.0212766 & 0.033064649 & 0.009950249 & 0 & 0.007580231 \\
\hline Harrachov (CZE) & 0.004975124 & 48 & 0.02083333 & 0.032011467 & 0 & 0 & 0.004272244 \\
\hline
\end{tabular}

Source: own study using Gephi software.

Tab. 4. Values of factors determining network parameters

\begin{tabular}{|c|c|c|c|c|}
\hline Average Clustering Coefficient & AVERAGE PATH LENGTH & DiAMETER & RADIUS OF A NETWORK & AVERAGE NODES DEGREE \\
\hline 0.071617162 & 16.704694350032018 & 48 & 25 & 3.03960396 \\
\hline
\end{tabular}

Source: own study using Gephi software and on the basis of (Tab. 3). 


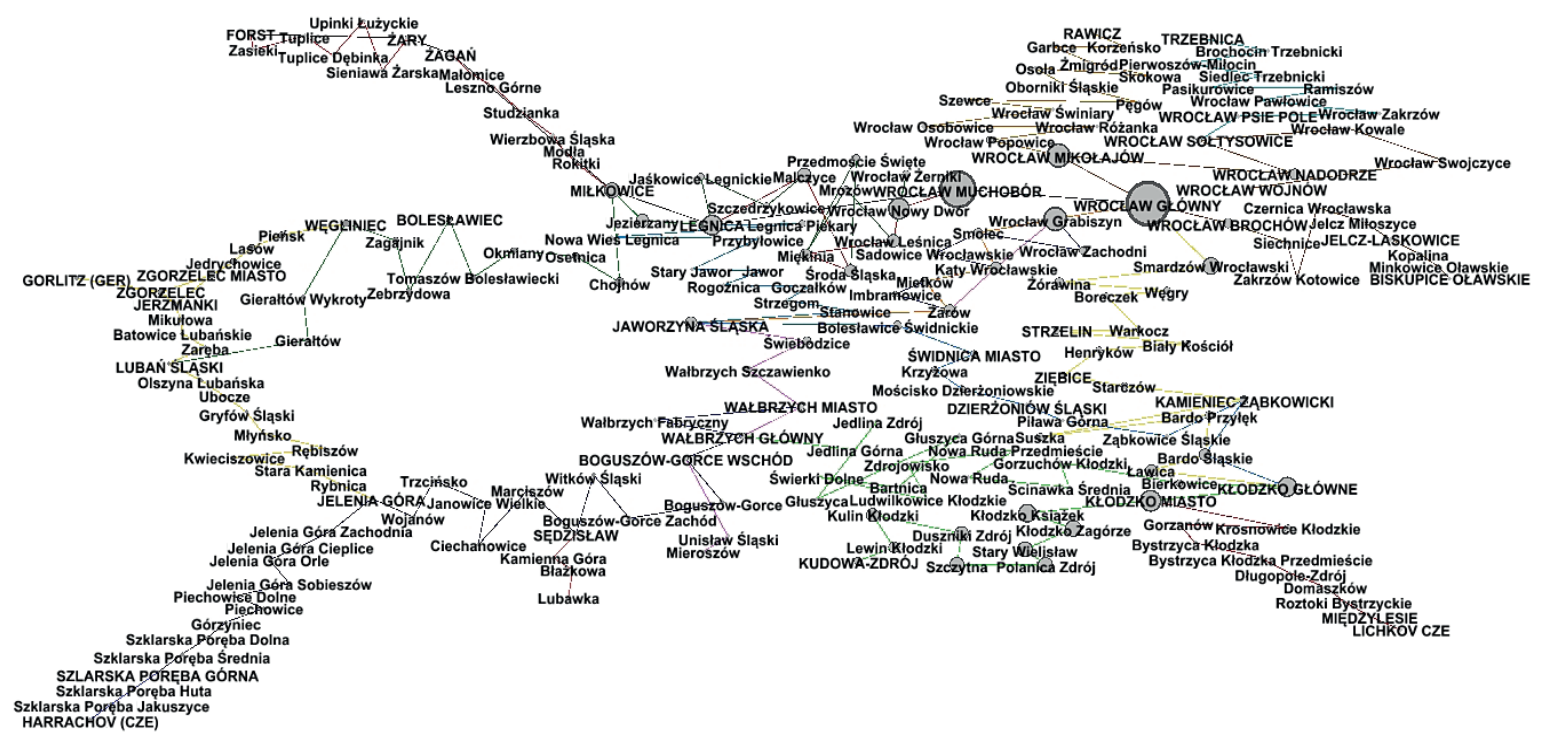

Fig. 8. Eigenvector coefficient for the analysed network

Source: own study using Gephi software.

\section{DISCUSSION OF THE RESULTS: ANALYSIS OF THE NETWORK STRUCTURE - PROPOSED MODIFICATION}

As part of the analysis of the structure of the connections network used by Koleje Dolnośląskie, it was proposed to introduce modifications that improved the network by increasing its cross-linking. As already mentioned, network modification, and quality analysis and evaluation are important elements of business management. As part of the research, it was proposed to add connections to the existing network. The implementation of the proposal is enabled by the railway network in the Lower Silesian Voivodship. The following connections were added to the analysed structure:

1. Wrocław Wojnów - Dobrzykowice Wr. - Nadolice Wielkie - Chrząstawa Wlk. - Jelcz Miłoszyce;

2. Wrocław Różanka-Wrocław Sołtysowice;

3. Wrocław Nowy Dwór - Wrocław Zachodni;

4. Jelenia Góra - Pilchowice Nielestno - Wleń Lwówek Śląski - Niwnice - Nowogrodziec Zebrzydowa;

5. Legnica - Jerzmanice - Wojcieszów - Marciszów;

6. Węgliniec - Ruszów - Jankowa Żagańska - Żagań and Żary;

7. Lwówek Śląski - Jerzmanice;

8. Marciszów - Strzegom;

9. Strzegom - Malczyce.
The network with added connections is shown in Fig. 9.

Indicators were also calculated for individual network nodes for networks after the modification. The obtained calculation results are presented in Tab. 5 (for selected stations).

As shown in Tab. 5 and Fig. 10-12, the main stations have not changed, but there has been an increase in network cross-linking.

Then, coefficients determining the state of the network as a whole were calculated. The obtained values of coefficients are presented in Tab. 6 .

Then, the comparison was made of values of coefficients determining the network parameters before and after the proposed modification. The compared data is presented in Tab. 7.

As shown in Tab. 7, the introduction of new stations and connections to the carrier network contributed to the improvement of their parameters. Only Average Clustering Coefficient deteriorated, which means the deterioration of the ability to form groups (clusters) of stations directly related to one another. According to the authors, it is an apparent deterioration as it is the result of increasing the availability of transport networks through the addition of new nodes (stations) and connections. This statement is supported by improved network parameters. It is clearly visible that the average length of the path has been reduced, i.e. a journey from node A to node B is faster at least theoretically (through a smaller number of nodes). The situation looks similar to the radius of the network and its diameter, which diminishes in 


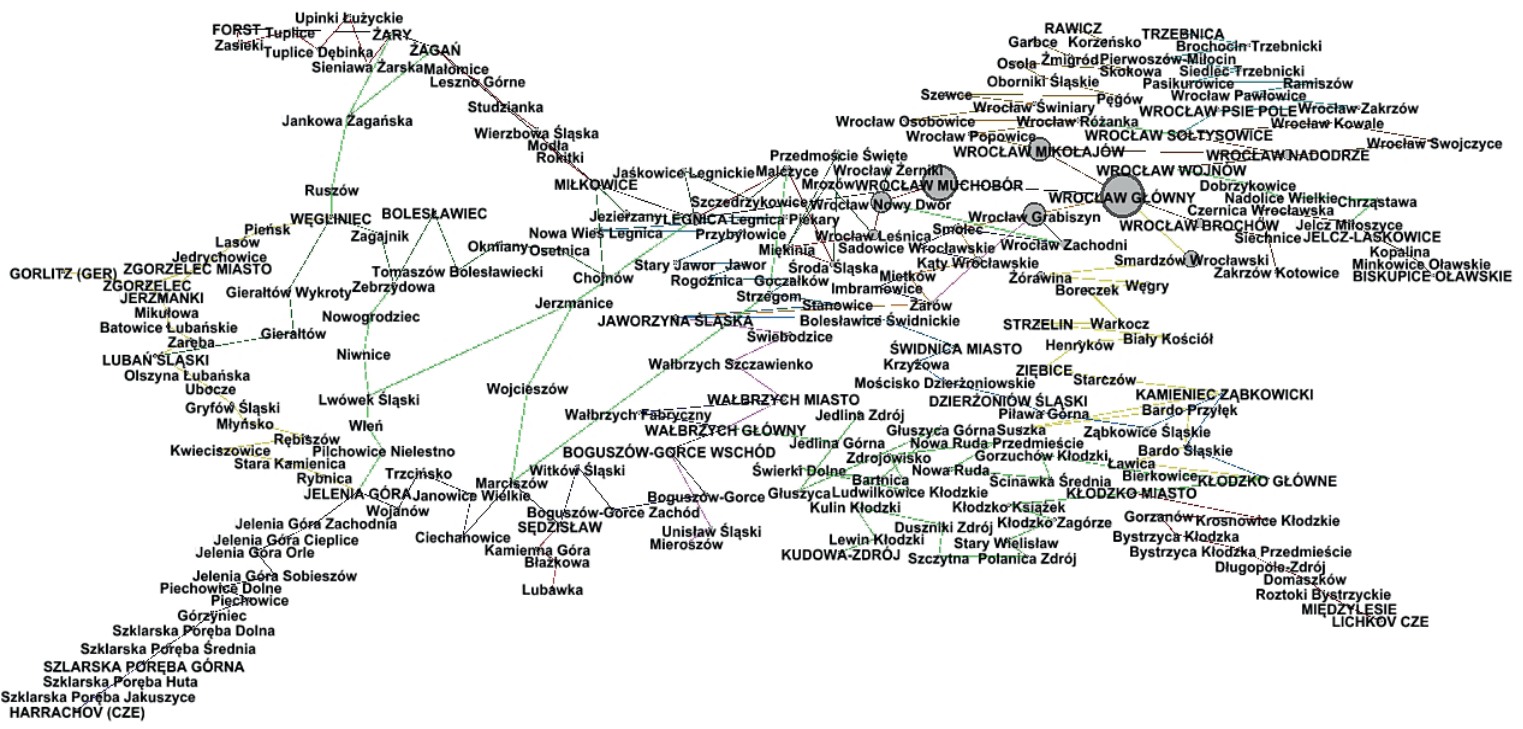

Fig. 9. Connections network used by Koleje Dolnośląskie with additional proposed connections

Source: own elaboration based on (Fig. 3 and 4).

Tab. 5. Indicators calculated for particular stops (nodes) of the Koleje Dolnośląskie network with the modification

\begin{tabular}{|c|c|c|c|c|c|c|c|}
\hline CITY (NODE) & $\begin{array}{l}\text { NORMALIZED } \\
\text { DEGREE }\end{array}$ & $\begin{array}{l}\text { ECCENTRIC- } \\
\text { ITY }\end{array}$ & RADIUS & $\begin{array}{l}\text { CLOSENESS } \\
\text { CENTRALITY }\end{array}$ & $\begin{array}{l}\text { BETWEENNESS } \\
\text { CENTRALITY }\end{array}$ & CLUSTERING & $\begin{array}{l}\text { EIGENCEN- } \\
\text { TRALITY }\end{array}$ \\
\hline Wrocław Główny & 0.061032864 & 23 & 0.04347826 & 0.11576087 & 0.391290999 & 0 & 1 \\
\hline Wrocław Brochów & 0.009389671 & 24 & 0.04166667 & 0.104874446 & 0.083255824 & 0 & 0.145903823 \\
\hline Jelcz Miłoszyce & 0.014084507 & 28 & 0.03571429 & 0.076453697 & 0.053315174 & 0 & 0.015025101 \\
\hline Jelcz-Laskowice & 0.009389671 & 29 & 0.03448276 & 0.07118984 & 0.027903269 & 0 & 0.010996589 \\
\hline Biskupice Oławskie & 0.004694836 & 32 & 0.03125 & 0.058807289 & 0 & 0 & 0.004213444 \\
\hline Wrocław Mikołajów & 0.028169014 & 24 & 0.04166667 & 0.106766917 & 0.222816458 & 0 & 0.487666755 \\
\hline Wrocław Różanka & 0.014084507 & 26 & 0.03846154 & 0.091612903 & 0.099089822 & 0 & 0.035827756 \\
\hline Rawicz & 0.004694836 & 37 & 0.02702703 & 0.046844073 & 0 & 0 & 0.004205025 \\
\hline Wrocław Nadodrze & 0.018779343 & 25 & 0.04 & 0.098428835 & 0.110594384 & 0 & 0.172788688 \\
\hline Wrocław Sołtysowice & 0.023474178 & 26 & 0.03846154 & 0.091968912 & 0.117514837 & 0 & 0.078817379 \\
\hline Wrocław Psie Pole & 0.009389671 & 27 & 0.03703704 & 0.084792994 & 0.07263708 & 0 & 0.021852225 \\
\hline Trzebnica & 0.004694836 & 35 & 0.02857143 & 0.051300578 & 0 & 0 & 0.004205025 \\
\hline Wrocław Wojnów & 0.009389671 & 29 & 0.03448276 & 0.073727934 & 0.014671362 & 0 & 0.009491183 \\
\hline Strzelin & 0.018779343 & 26 & 0.03846154 & 0.081484315 & 0.091327451 & 0 & 0.057918505 \\
\hline Ziębice & 0.018779343 & 29 & 0.03448276 & 0.072745902 & 0.077433962 & 0 & 0.064799391 \\
\hline Kamieniec Ząbkowicki & 0.028169014 & 29 & 0.03448276 & 0.072572402 & 0.22369535 & 0 & 0.115888142 \\
\hline Kłodzko Główne & 0.037558685 & 31 & 0.03225806 & 0.066026038 & 0.196072395 & 0.166666667 & 0.374518125 \\
\hline Kłodzko Miasto & 0.037558685 & 32 & 0.03125 & 0.062610229 & 0.159048631 & 0 & 0.415725032 \\
\hline Międzylesie & 0.009389671 & 40 & 0.025 & 0.042379626 & 0.009389671 & 0 & 0.00746195 \\
\hline Lichkov (CZE) & 0.004694836 & 41 & 0.02439024 & 0.040664376 & 0 & 0 & 0.004205025 \\
\hline Kudowa-Zdrój & 0.014084507 & 41 & 0.02439024 & 0.040664376 & 0 & 0 & 0.094983554 \\
\hline Jaworzyna Śląska & 0.037558685 & 21 & 0.04761905 & 0.109118852 & 0.290992003 & 0 & 0.205175045 \\
\hline Wrocław Zachodni & 0.014084507 & 24 & 0.04166667 & 0.103700097 & 0.005569894 & 0.333333333 & 0.162088441 \\
\hline Świdnica Miasto & 0.018779343 & 23 & 0.04347826 & 0.095945946 & 0.184653459 & 0 & 0.073568432 \\
\hline Dzierżoniów Śląski & 0.014084507 & 26 & 0.03846154 & 0.081703107 & 0.167395611 & 0 & 0.03120762 \\
\hline
\end{tabular}


Tab. 5. Continued: Indicators calculated for particular stops (nodes) of the Koleje Dolnośląskie network with the modification

\begin{tabular}{|c|c|c|c|c|c|c|c|}
\hline CITY (NODE) & $\begin{array}{c}\text { NORMALIZED } \\
\text { DEGREE }\end{array}$ & $\begin{array}{c}\text { ECCENTRIC- } \\
\text { ITY }\end{array}$ & RADIUS & $\begin{array}{l}\text { CLOSENESS } \\
\text { CENTRALITY }\end{array}$ & $\begin{array}{c}\text { BETWEENNESS } \\
\text { CENTRALITY }\end{array}$ & CLUStering & $\begin{array}{l}\text { EIGENCEN- } \\
\text { TRALITY }\end{array}$ \\
\hline Wałbrzych Główny & 0.023474178 & 24 & 0.04166667 & 0.081986143 & 0.086967146 & 0.166666667 & 0.05170528 \\
\hline Wałbrzych Miasto & 0.018779343 & 24 & 0.04166667 & 0.0863047 & 0.078660525 & 0.333333333 & 0.054814794 \\
\hline Boguszów-Gorce Wschód & 0.018779343 & 25 & 0.04 & 0.079924953 & 0.042734651 & 0 & 0.040209956 \\
\hline Malczyce & 0.03286385 & 23 & 0.04347826 & 0.115384615 & 0.197801665 & 0 & 0.287913585 \\
\hline Wrocław Nowy Dwór & 0.03286385 & 25 & 0.04 & 0.105654762 & 0.029781542 & 0.166666667 & 0.464967642 \\
\hline Wrocław Muchobór & 0.037558685 & 24 & 0.04166667 & 0.11525974 & 0.263636556 & 0 & 0.830075071 \\
\hline Strzegom & 0.018779343 & 22 & 0.04545455 & 0.113297872 & 0.261755671 & 0 & 0.07783938 \\
\hline Żagań & 0.023474178 & 26 & 0.03846154 & 0.102749638 & 0.20248157 & 0.166666667 & 0.103484379 \\
\hline Żary & 0.023474178 & 27 & 0.03703704 & 0.09475089 & 0.055142174 & 0.166666667 & 0.068336354 \\
\hline Forst & 0.009389671 & 28 & 0.03571429 & 0.086761711 & 0.018469306 & 0 & 0.021419112 \\
\hline Bolesławiec & 0.018779343 & 30 & 0.03333333 & 0.079477612 & 0.004637393 & 0 & 0.065067299 \\
\hline Zebrzydowa & 0.023474178 & 29 & 0.03448276 & 0.085714286 & 0.028441881 & 0 & 0.073554421 \\
\hline Węgliniec & 0.028169014 & 29 & 0.03448276 & 0.08489438 & 0.135313643 & 0 & 0.084645059 \\
\hline Lubań Śląski & 0.014084507 & 32 & 0.03125 & 0.07029703 & 0.042896173 & 0 & 0.015429683 \\
\hline Zgorzelec Miasto & 0.023474178 & 33 & 0.03030303 & 0.06480073 & 0.033885909 & 0.333333333 & 0.075333652 \\
\hline Zgorzelec & 0.023474178 & 34 & 0.02941176 & 0.061154177 & 0.009389671 & 0.333333333 & 0.064591327 \\
\hline Jerzmanki & 0.014084507 & 34 & 0.02941176 & 0.061365601 & 0.009365544 & 0.333333333 & 0.040125841 \\
\hline Gorlitz (GER) & 0.009389671 & 35 & 0.02857143 & 0.057645467 & 0 & 0 & 0.032498012 \\
\hline Sędzisław & 0.014084507 & 24 & 0.04166667 & 0.098611111 & 0.080241258 & 0 & 0.021015194 \\
\hline Marciszów & 0.018779343 & 23 & 0.04347826 & 0.106927711 & 0.157245796 & 0 & 0.037049332 \\
\hline Jelenia Góra & 0.018779343 & 28 & 0.03571429 & 0.087474333 & 0.164932364 & 0 & 0.021818036 \\
\hline Szlarska Poręba Górna & 0.009389671 & 38 & 0.02631579 & 0.048354143 & 0.027903269 & 0 & 0.009127539 \\
\hline Harrachov (CZE) & 0.004694836 & 41 & 0.02439024 & 0.042303873 & 0 & 0 & 0.004205025 \\
\hline Dobrzykowice & 0.009389671 & 30 & 0.03333333 & 0.069155844 & 0.006211799 & 0 & 0.009294607 \\
\hline Nadolice Wielkie & 0.009389671 & 30 & 0.03333333 & 0.068754035 & 0.005414563 & 0 & 0.009614059 \\
\hline Chrząstawa & 0.009389671 & 29 & 0.03448276 & 0.072375127 & 0.012312871 & 0 & 0.011062289 \\
\hline Pilchowice Nielestno & 0.009389671 & 28 & 0.03571429 & 0.090638298 & 0.098845473 & 0 & 0.013683839 \\
\hline Wleń & 0.009389671 & 27 & 0.03703704 & 0.097304705 & 0.105984525 & 0 & 0.013572447 \\
\hline Lwówek Śląski & 0.014084507 & 26 & 0.03846154 & 0.105133268 & 0.14252879 & 0 & 0.027273728 \\
\hline Niwnice & 0.009389671 & 27 & 0.03703704 & 0.097171533 & 0.037159916 & 0 & 0.014993587 \\
\hline Nowogrodziec & 0.009389671 & 28 & 0.03571429 & 0.090754154 & 0.030441971 & 0 & 0.023155518 \\
\hline Jerzmanice & 0.014084507 & 25 & 0.04 & 0.111811024 & 0.152985494 & 0 & 0.08618425 \\
\hline Wojcieszów & 0.009389671 & 24 & 0.04166667 & 0.108121827 & 0.033682055 & 0 & 0.027143182 \\
\hline Ruszów & 0.009389671 & 28 & 0.03571429 & 0.089121339 & 0.120640242 & 0 & 0.031666199 \\
\hline Jankowa Żagańska & 0.014084507 & 27 & 0.03703704 & 0.095515695 & 0.127165136 & 0.333333333 & 0.04663749 \\
\hline
\end{tabular}

Source: own study using Gephi software.

Tab. 6. Values of coefficients defining network parameters after modification

\begin{tabular}{|c|c|c|c|c|}
\hline $\begin{array}{l}\text { Average Clustering } \\
\text { CoEfFICIENT }\end{array}$ & $\begin{array}{l}\text { AVERAGE PATH } \\
\text { LENGTH }\end{array}$ & DIAMETER & $\begin{array}{l}\text { RADIUS OF } \\
\text { A NETWORK }\end{array}$ & $\begin{array}{l}\text { AVERAGE NODES } \\
\text { DEGREE }\end{array}$ \\
\hline 0.066733422 & 13.63279365 & 41 & 21 & 3.074766355 \\
\hline
\end{tabular}

Source: own study using Gephi software and based on (Tab. 5). 
Tab. 7. Values of coefficients determining network parameters before and after the modification

\begin{tabular}{|l|r|r|r|r|r|}
\hline & $\begin{array}{c}\text { Average Cluster- } \\
\text { ING COEFFICIENT }\end{array}$ & AVERAGE PATH LENGTH & \multicolumn{1}{|c|}{ DiAMETER } & \multicolumn{1}{c|}{$\begin{array}{c}\text { RADIUS OF } \\
\text { A NETWORK }\end{array}$} & $\begin{array}{c}\text { AVERAGE NODES } \\
\text { DEGREE }\end{array}$ \\
\hline Original network & 0.071617162 & 16.704694350032018 & 48 & 25 & 3.03960396 \\
\hline $\begin{array}{l}\text { Network after } \\
\text { modification }\end{array}$ & 0.066733422 & 13.63279365 & 41 & 3.074766355 \\
\hline $\begin{array}{l}\text { The effect of } \\
\text { modification }\end{array}$ & $\begin{array}{l}\text { Deterioration of } \\
\text { the parameter }\end{array}$ & $\begin{array}{l}\text { Improvement of } \\
\text { the parameter }\end{array}$ & $\begin{array}{l}\text { Improvement of } \\
\text { the parameter }\end{array}$ & $\begin{array}{l}\text { Improvement of } \\
\text { the parameter }\end{array}$ & $\begin{array}{l}\text { Improvement of } \\
\text { the parameter }\end{array}$ \\
\hline
\end{tabular}

Source: own study using Gephi software and based on (Tab. 3 and 5).

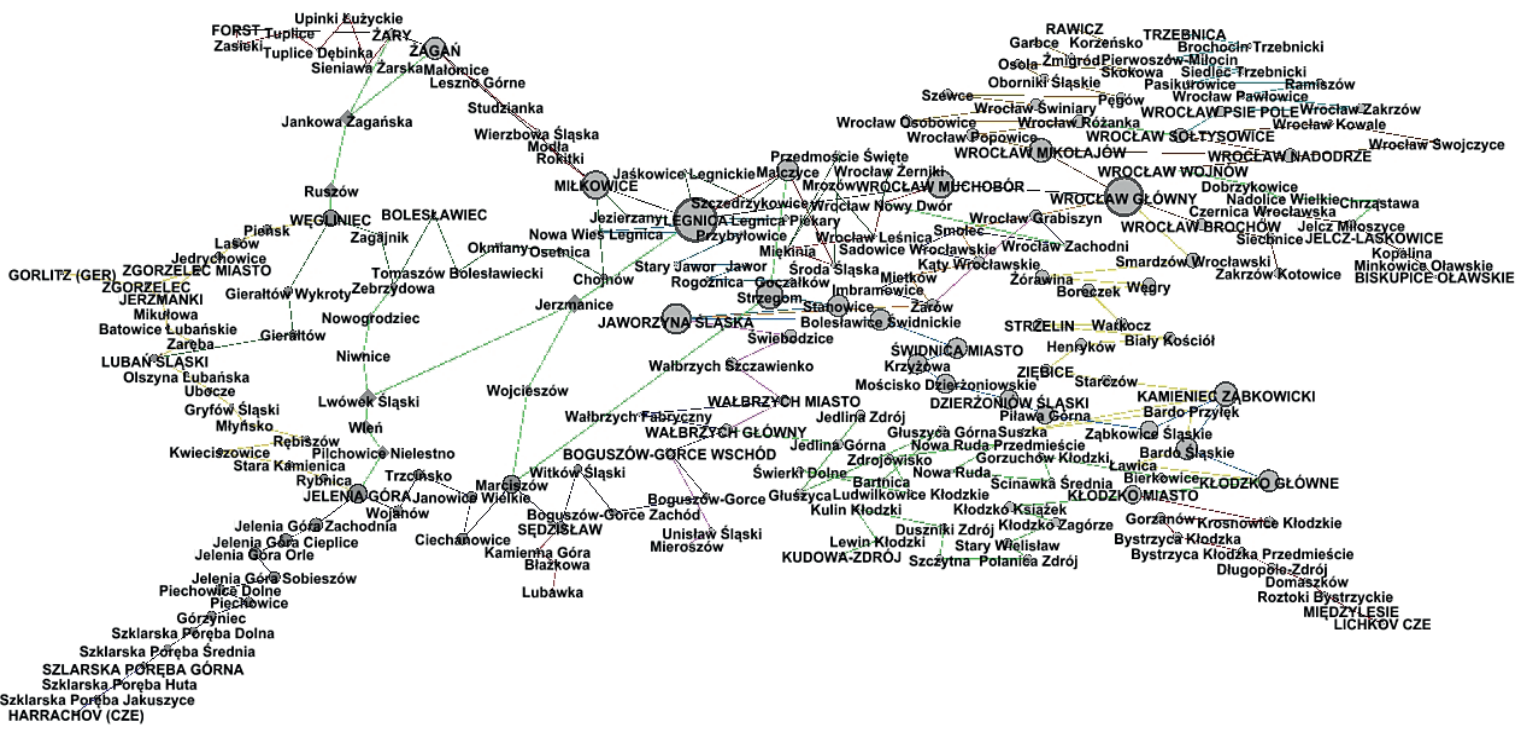

Fig. 10. Connections network used by Koleje Dolnośląskie with additional proposed connections

Source: own study using Gephi software.

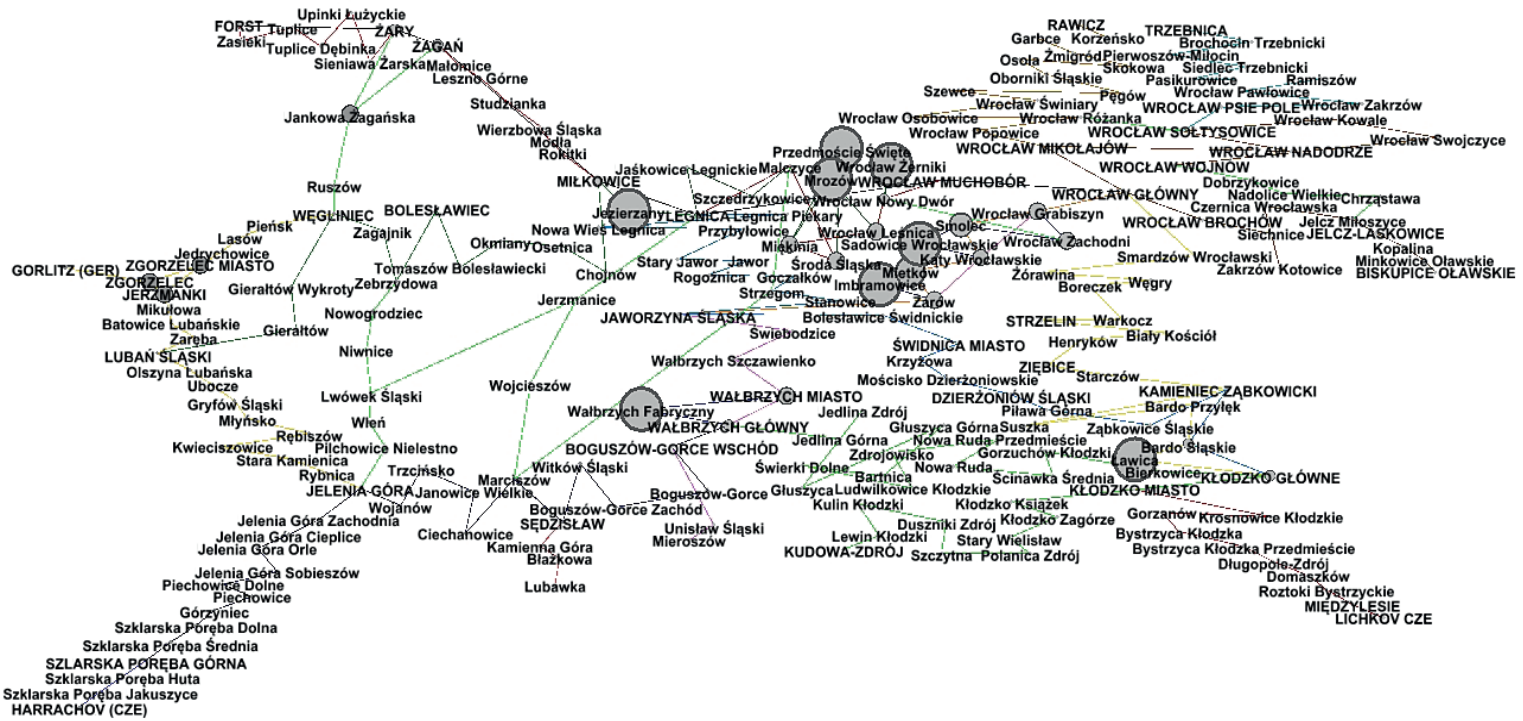

Fig. 11. Clusterisation coefficient for the analysed network after the modification

Source: own study using Gephi software. 


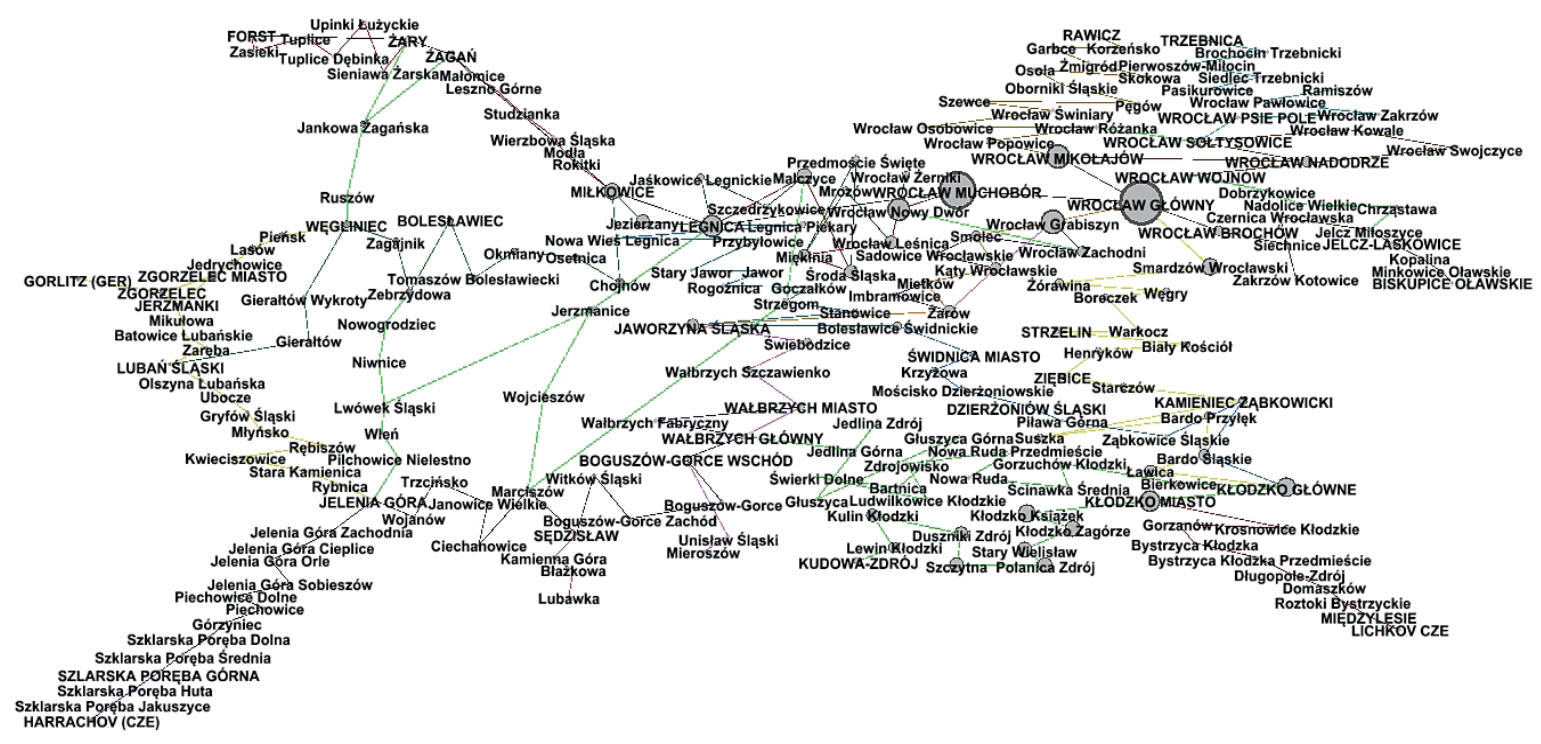

Fig. 12. Eigenvector coefficient for the analysed network after the modification

Source: own study using Gephi software.

value as a smaller number of stations need to be passed on the way from point $\mathrm{A}$ to point $\mathrm{B}$. The obtained average nodes degree also indicates the improvement of the network parameters, showing an increase in the average number of nodes to which the node is connected, which means the network of connections has grown and accessibility of the network has increased.

\section{CONCLUSIONS}

Transport networks are essential elements of the modern economy. Competition in the field of transport services in connection with traveller preferences of transport branches means that maintaining existing customers and acquiring new ones requires carriers to continuously improve their services. One of the elements of competitive advantage may be to improve the structure of the connections network to increase service availability. The analysed carrier Koleje Dolnośląskie has considerably increased the number of passengers carried in recent years; however, efforts should still be made to attract new customers (passengers).

The article proposed to introduce additional connections based on calculation results. They would contribute to the increase in the cross-linking of the connections structure, and this could, in turn, contribute to an increase in the number of travellers. Naturally, before making changes to the connections structure, it is required to analyse and forecasts the real interest of travellers in using the proposed new connections. The analysis can be made using Gephi software, which was used for analyses presented in this article.

\section{LITERATURE}

Amaral, L., Scala, A., Barthelemy, M., \& Stanley, H. E. (2000). Classes of small-world networks. Proceedings of the National Academy of Sciences of the United States of America, 97(21), 11149-11152.

Arenas, A., Danon, L., Diaz-Guilera, A., Gleiser, P. M., \& Guimera, R. (2003). Community analysis in social networks. European Physical Journal B, 38(2), 373-380.

Badura, D. (2017). Urban traffic modeling and simulation. Forum Scientiae Oeconomia, 5(4), 85-97.

Bukowski, L. (2014). Total Logistic Management: istota koncepcji Kompleksowego Zarządzania Logistycznego [Total Logistic Management: Core Fundamentals of Total Logistic Management]. Czasopismo Logistyka, 4(2), 1705-1712.

Bukowski, L. (2015). Concept of the quantitative risk generalized model assessment. Forum Scientiae Oeconomia, 3(2), 5-16.

Bullmore, E., \& Sporns, O. (2009). Complex brain networks: graph theoretical analysis of structural and functional systems. Nature Reviews. Neurology, 10(3), 186-198.

Butts, C. T. (2008). Social network analysis, A methodological introduction. Asian Journal Of Social Psychology, 11, 13-41.

Dunn, S., \& Wilkinson, S. (2017). Hazard tolerance of spatially distributed complex networks. Reliability Engineering and System Safety, 157, 1-12. 
Eusgeld, I., Kroger, W., Sansavini, G., Schlapfer, M., \& Zio, E. (2009). The role of network theory and object-orientated modeling within a frame work for the vulnerability analysis of critical infrastructures. Reliability Engineering and System Safety, 92(5), 954-63.

Gephi. (2018). Gephi forums. Retrieved from http://forumgephi.org

Heymann, S. (2015). Gephi. GitHub. Retireved from https:// github.com/gephi/gephi/wiki

Kerap, S., Pangemanan, S., \& Tumiwa, J. (2017). Analysing logistic management of culinary small and medium enterprises in Manado. Jurnal Riset Ekonomi, Manajemen, Bisnis dan Akuntansi, 5(2), 2569-2578.

Koleje Dolnośląskie S.A. [Lower Silesian Railways]. (2016). Koleje Dolnoślaskie. Raport Roczny 2016 [Lower Silesian Railways. Annual Report 2016]. Retrieved from https://m.kolejedolnoslaskie.eu/pl

Koleje Dolnośląskie S.A. [Lower Silesian Railways]. (2018). Diagram of the connection network of Koleje Dolnoślaskie. Retrieved from https://www.kolejedolnoslaskie.eu/pl/rozk\%C5\%82ad-jazdy/mapapo\%C5\%82\%C4\%85cze\%C5\%84.html

Krykawskyy, Y., Margita, N., \& Voronina, R. (2015). Research of urban logistics indices assessment. Forum Scientiae Oeconomia, 3(2), 55-64.

La Rovere, S., \& Vestrucci, P. (2012). Investigation of the structure of a networked system. Reliability Engineering and System Safety, 107, 214-223.

Li, H., Guo, X. M., Xu, Z., \& Hu, X. B. (2014). A study on the spatial vulnerability of the civil aviation network system in China. Proceedings of the IEEE 17th international conference on intelligent transportation systems, Qingdao, 2650-2655.

Mesjasz-Lech, A. (2014). Development of public transport in the city - a challenge for urban logistics in terms of sustainable development. Forum Scientiae Oeconomia, 2(4), 63-75.

Newman, M. E. J. (2010). Networks: An Introduction. New York, USA: Oxford University Press.

Newman, M. E. J., Watts, D. J., \& Strogatz, S. H. (2002). Random graph models of social networks. Proceedings of the National Academy of Sciences of the United States of America, 99(1), 2566-2572.

Ogólnopolska baza kolejowa [National Railway Database]. (2018). Railway network in the Lower Silesia Voivodeship. Retrieved from: http://www.bazakolejowa.pl

Otte, E., \& Rousseau, R. (2002). Social network analysis. A powerful strategy, also for the information sciences. Journal of Information Science, 28, 441-453.

Ouyang, M., Pan, Z., Hong, L., \& He, Y. (2015). Vulnerability analysis of complementary transportation systems with applications to railway and airline systems in China. Reliability Engineering \& System Safety, 142, 248-257.

Popp, J., Balogh, P., Oláh, J., Lengyel, P. (2018). Social Network Analysis of Scientific Articles Published by Food Policy. Sustainability, 10(3), 577-797.
Royal Academy of Engineering. (2011). Infrastructure engineering and climate change adaptation - ensuring services in an uncertain future. London, England: The Royal Academy of Engineering. Retrieved from https://assets.publishing.service.gov.uk/government/uploads/system/uploads/attachment_data/ file/183536/infrastructure-rae-report.pdf

Rual, J.-F., Venkatesan, K., Hao, T., Hirozane-Kishikawa, T., Dricot, A., Li, N., Berriz, G. F., Gibbons, F. D., Dreze, M., Ayivi-Guedehoussou, N., Klitgord, N., Simon, C., Boxem, M., Milstein, S., Rosenberg, J., Goldberg, D. S., Zhang, L. V., Wong, S. L., Franklin, G., Li, S., Albala, J. S., Lim, J., Fraughton, C., Llamosas, E., Cevik, S., Bex, C., Lamesch, P., Sikorski, R. S., Vandenhaute, J., Zoghbi, H. Y., Smolyar, A., Bosak, S., Sequerra, R., Doucette-Stamm, L., Cusick, M. E., Hill, D. E., Roth, F. P., \& Vidal, M. (2005). Towards a proteomescale map of the human protein-protein interaction network. Nature, 437(7062), 1173-1178.

Sobczak, P. (2017). Analiza strukturalna sieci transportowej Kolei Mazowieckich [Structural Analysis of Koleje Mazowieckie Transport Network]. Zeszyty Naukowe Politechniki Śląskiej Seria: Organizacja i Zarządzanie, 103, 217-230.

Sołtysik, M. (2000). Zarzadzanie logistyczne [Logistics management]. Katowice, Poland: Wydawnictwo Akademii Ekonomicznej im. Karola Adamieckiego.

Sporns, O. (2002). Network analysis, complexity, and brain function. Complexity, 8(1), 56-60.

Stam, C. J., \& Reijneveld, J. C. (2007). Graph theoretical analysis of complex networks in the brain. Nonlinear Biomedical Physics, 1(3), 1-19.

Stawiarska, E., \& Sobczak, P. (2018). The Impact of Intelligent Transportation System Implementations on the Sustainable Growth of Passenger Transport in EU Regions. Sustainability, 10, 1318.

Szołtysek, J. (2014). Mobility - a challenge for cities. Forum Scientiae Oeconomia, 2(4), 19-33.

Tarapata, Z. (2015). Modelling and analysis of transportation networks using complex networks: Poland case study. The Archives of Transport, 36(4), 55-65.

Urząd Transportu Kolejowego UTK [Polish Office of Rail Transport]. (2018). Statistical data. Retrieved from https://www.utk.gov.pl

Valverde, S., \& Solé, R. V. (2003). Hierarchical small worlds in software architecture. Dynamics of Continuous, Discrete and Impulsive Systems Series B: Applications and Algorithms, 14(S6), 1-11.

Wilkinson, S., Dunn, S., \& Ma, S. (2012). The vulnerability of the European air traffic network to spatial hazards. Natural Hazards, 60(3), 1027-1036.

Witkowski, J. (1995). Strategia logistyczna przedsiębiorstw przemysłowych [Logistics strategy of industrial enterprises]. Wrocław, Poland: Wydawnictwo Akademii Ekonomicznej we Wrocławiu.

Zirkelbach, C., Hasselbring, W., \& Carr, L. (2015). Combining Kieker with Gephi for Performance Analysis and Interactive Trace Visualization. Symposium on Software Performance: Joint Developer and Community Meeting of Descartes/Kieker/Palladio, 26-28. 